\title{
PENINGKATAN PEMASARAN PRODUK KERAJINAN BAMBU DI DUSUN SANGGRAHAN I, DESA MUNTUK, DLINGO, BANTUL
}

\section{ENHANCEMENT OF BAMBOO HANDICRAFT PRODUCTS MARKETING IN SANGGRAHAN I, MUNTUK VILLAGE, DLINGO, BANTUL}

\author{
${ }^{1)}$ Ani Yunita, ${ }^{2)}$ Heri Purwanto \\ ${ }^{1,2)}$ Program Studi Ilmu Hukum, Fakultas Hukum, Universitas Muhammadiyah Yogyakarta \\ J1. Brawijaya, Tamantirto, Kasihan, Bantul, 55183.Telp (0274) 387646 \\ Email: aniyunita@umy.ac.id
}

\begin{abstract}
ABSTRAK
Program pengabdian ini dilatarbelakangi oleh minimnya akses pasar dan informasi pemasaran di Dusun Sanggrahan I, Desa Muntuk, Dlingo, DIY. Program ini bertujuan untuk meningkatkan kemampuan enterpreneurship, memperluas akses pasar dan akses informasi pemasaran baik secara pemasaran manual maupun online produk kerajinan bambu bagi Kelompok PKK di Dusun Sanggarahan I tersebut. Metode pelaksanaan yang dilakukan dalam program kegiatan pengabdian masyarakat ini ialah memberikan penyuluhan dan pelatihan dengan metode ceramah dan tanya jawab serta pendampingan pemasaran oleh Tim Pelaksana Program Pengabdian dengan metode pendampingan praktek. Pelaksanaan pengabdian ini memiliki sasaran yaitu Kelompok Ibu PKK Dusun Sanggrahan 1. Hasil dan pembahasan dalam pengabdian ini ialah kelompok PKK Dusun Sanggrahan 1 yang semulapengetahuan anggota kelompok PKK hanya mendapatkan pengetahuan berwirausaha 50 persen menjadi meningkat 75 persen dapat mengetahui dan memahami mengenai pentingnya berwirausaha dan cara pembuatan kerajinan bambu. Semula ketrampilan dan kreatifitas anggota kelompok PKK masih sangat terbatas berkisar 60 persen dalam membuat produk berupa tampah, tambir, irik, kalo dan ceting menjadi 90 persen lebih trampil, kreatif dan inovatif dalam membuat variasi produk kerajinan bambu berupa tempat pensil, tempat tisu, tempat permen dan tempat boneka.Ketrampilam anggota PKK dalam memasarkan hasil kerajinan bambu sebelumnya hanya 40 persen atau masih sangat tergantung dengan tengkulak maka setelah adanya pengabdian ini ketrampilan kelompok PKK melakukan pemasaran kerajinan bambu baik secara manual dengan menawarkan ke toko/swalayan maupun online melalui akun whatsapp, instagram dan facebook menjadi meningkat 70 persen lebih trampil.
\end{abstract}

Kata kunci: Peningkatan; Pemasaran; Kerajinan Bambu; Kelompok PKK

\section{ABSTRACT}

The background community service program is the lack of market and marketing information access in Sanggrahan, Muntuk Village, Dlingo, Special Regoin of Yogyakarta. This program aims to improve entrepreneurship skills, expand market and marketing information access both in manual marketing and online bamboo handicraft products for the PKK Group in the Sanggarahan I Village. The method of implementation carried out in the program of community service activities is to provide counseling and training with lecture and question and answer methods and marketing assistance by the Implementation Team of the Community Service Program with practical assistance methods. The implementation of this service had the target of PKK Sanggrahan 1. The results and discussions in this service include the PKK group in Dusun Sanggrahan 1, which was previously the knowledge of PKK group members who only 50 percent entrepreneurial knowledge up to 75 percent able to know and understand the importance of entrepreneurship and how to make bamboo handicrafts.Previously, the skills and creativity of PKK group members were still very limited, ranging from 60 percent in making products in the form of tampah, tambir, irik, kalo and ceting, to be 90 percent more skilled, creative and innovative in making variations of bamboo handicraft products in the form of pencil cases, tissue boxes, candy containers and dollhouses.The skills of PKK members in marketing bamboo handicrafts previously were only 40 percent or still very dependent on middlemen, so after this dedication the PKK group's skills in marketing bamboo handicrafts either manually by offering to shops/ supermarkets or online through whatsapp accounts, Instagram and Facebook have increased 70 percent more skilled.

Keywords: Enhancement; Marketing; Bamboo Handicraft; PKK Group 


\section{PENDAHULUAN}

Dusun Sanggrahan 1 merupakan salah satu dusun dari Desa Muntuk, Kecamatan Dlingo, Bantul dengan jumlah masyarakat sebanyak 457 jiwa yang terdiri dari 4 RT (empat Rukun Tetangga). RukunTetangga di Pedukuhan Sanggrahan I yaitu RT 1 (43 Kepala Keluarga), RT 2 (26 Kepala Keluarga), RT 3 (29 Kepala Keluarga) dan RT 4 (27 Kepala Kelaurga). Mayoritas masyarakat lulus di jenjang pendidikan SD serta mayoritas berprofesi sebagai pengrajin bambu. Rendahnya pendidikan yang didapatkan membuat masyarakat Dusun Sanggrahan I kurang mendapatkan pemahaman tentang informasi pemasaran.

Pemasaran adalah suatu proses sosial dan manajerial yang didalamnya individu dan kelompok mendapatkan apa yang mereka butuhkan dan inginkan dengan menciptakan, menawarkan dan mempertukarkan produk dengan pihak lain (Kotler, 2003). Banyak yang menganggap bidang ini identik atau sama dengan bidang penjualan. Sesungguhnya pemasaran memiliki arti yang luas daripada penjualan.

Bidang penjualan merupakan bagian dari bidang pemasaran, sekaligus merupakan bagian terpenting dari bidang pemasaran itu sendiri. Pemasaran berarti bekerja dengan pasar untuk mewujudkan pertukaran potensial dengan maksud memuaskan kebutuhan dan keinginan manusia. Jika perusahaan menaruh perhatian lebih banyak untuk terus menerus mengikuti perubahan kebutuhan dan keinginan baru, mereka tidak akan mengalami kesulitan untuk mengenali peluang-peluangnya. Oleh karena itu, dalam pengabdian ini diperlukan pemasaran produk sehingga produk kerajinan bambu dapat diminati oleh banyak konsumen.

Dusun Sanggrahan I merupakan salah satu dusun yang mempunyai sebagian masyarakat bekerja dengan cara membuat kerajinan bambu. Masyarakat Dusun Sanggrahan memiliki ketrampilan dalam membuat kerajinan bambu yang sangat baik (Anonim, 2018). Kelompok anggota PKK biasanya membuat keperluan rumah tangga seperti tampah, tambir, irik, kalo dan ceting. Terdapat permasalahan mitra terkait minimnya akses pemasaran dan kemampuan berwirausaha, padahal jika dikembangkan akan memberikan manfaat yang lebih banyak dan dapat memperluas pemasaran produk kerajinan bambu.

Pemasaran kerajinan bambu saat ini masih dilakukan secara perorangan dengan membuka home industry atau langsung dijual ke tengkulak sehingga harga jual masih rendah dan pemasaran belum meluas ke berbagai wilayah diluar Yogyakarta. Pemasaran atau promosi menggunakan media internet berbeda dengan mass marketing dan direct marketing yang biasanya bersifat pasif (pemberian informasi satu arah), sifat internet marketing ini adalah aktif atau dengan kata lain, Internet marketing mempunyai keunggulan karena memungkinkan konsumen berinteraksi dengan perusahaan melalui iklan (Nurdjanah, et, all., 2019).

Pemasaran melalui media internet belum dilakukan karena sebagian besar masyarakat terutama kelompok anggota PKK Dusun Sanggrahan I sudah berusia 30-60 tahun sehingga mereka belum memahami mengenai cara pemasaran online melalui media sosial.

Program ini bertujuan untuk meningkatkan kemampuan enterpreneurship, memperluas akses pasar dan akses informasi pemasaran produk kerajinan bambu baik secara manual maupun online Di Dusun Sanggrahan I, Desa Muntuk, Kecamatan Dlingo, Daerah Istimewa Yogyakarta.

\section{METODE}

Sasaran yang menjadi mitra kegiatan pengabdian masyarakat ini adalah kelompok Ibu-ibu PKK di Dusun Sanggrahan I, Desa Muntuk, Dlingo, Bantul yang terdiri dari 30 anggota PKK. Sebagian besar anggota PKK ialah ibu rumah tangga yang memiliki banyak waktu luang. Mitra memiliki semangat dan keinginan yang sangat tinggi untuk membuat inovasi produk kerajinan bambu. 
Langkah-langkah kegiatan dalam kegiatan pengabdian masyarakat antara lain sebagai berikut :

\section{Penyuluhan dan Praktek Pembuatan} Inovasi Produk

Penyuluhan dilakukan di awal program, dengan memberikan pengetahuan dan penyadaran mengenai pentingnya berwirausaha. Masyarakat juga diminta sharing mengenai pengalaman selama ini dalam pemasaran produk kerajinan bambu yang telah dilakukan oleh masyarakat Dusun Sanggarahan I. Penyuluhan dan praktek pembuatan inovasi produk ini mengundang nara sumber dari salah satu wirausahawan Di Sleman. Peserta pelatihan yaitu Kelompok PKK Dusun Sanggrahan I, Desa Muntuk, Dlingo, Bantul, DIY.

\section{Pelatihan}

Metode pelatihan untuk memberikan keterampilan pemasaran agar memiliki nilai jual yang tinggi. Pelatihan ini mengundang nara sumber dari salah satu Dosen Ekonomi Jurusan kewirausahaan. Peserta pelatihan yaitu Kelompok PKK Dusun Sanggrahan I, Desa Muntuk, Dlingo, Bantul, DIY. Pelatihan meliputi :

\section{a. Pelatihan pemasaran manual}

Pemasaran ialah salah satu sistem keseluruhan dari kegiatan-kegiatan bisnis yang ditujukan untuk merencanakan, menentukan harga, mempromosikan dan mendistribusikan barang atau jasa yang memuaskan kebutuhan baik kepada pembeli yang ada maupun pembeli potensial (Aini, Suprapto \& Khaudli, 2019). Pelatihan ini bertujuan untuk meningkatkan jiwa kewirausahaan (enterpreneurship) bagi mitra sehingga memiliki pola pikir yang terus berkembang. Keinginan berwirausaha biasanya muncul karena kegemaran terhadap jenis usaha, keinginan untuk mandiri, tuntutan kebutuhan serta impian personal. Secara sederhana arti wirausahawan adalah orang yang berjiwa berani mengambil resiko untuk membuka usaha dalam berbagai kesempatan sedangkan kewirausahaan merupakan suatu kemampuan dalam hal menciptakan kegiatan usaha (Rahmawati, et,all., 2019).
Wirausaha memerlukan kreatifitas agar produk terus berkembang dan berdampak pada peningkatan taraf ekonomi bagi anggota mitra.

b. Pelatihan pemasaran online

Pelatihan ini bertujuan untuk mengenalkan dan sekaligus mempraktekkan penjualan barang melalui situs yang sudah populer sebagai ecommerce seperti https://www.shopee.co.id. Selain itu, pelatihan juga memuat pemanfaatan layanan iklan gratis secara online. Selanjutnya pada tahap akhir marketing online terdapat tutorial penggunaan website milik kelompok mitra.

Program-program pelatihan dalam pengabdian masyarakat dikembangkan dengan metode yang lebih sederhana, yaitu dengan menyelenggarakan sarasehan dan diskusi santai/ informal sehingga masyarakat tidak terlalu berat dalam menerima materi-materi pelatihan. Metode pelatihan dengan diskusi informal bertujuan untuk mendorong partisipasi dan perhatian peserta yang lebih intens.

\section{Pendampingan}

Pendampingan praktek pemasaran bertujuan untuk memastikan bahwa programprogram pelatihan dapat berjalan lancar dan berkelanjutan. Tim pelaksana pengabdian juga melakukan kegiatan pendampingan dengan pemonitoran dan evaluasi secara rutin terkait pemasaran secara manual dan online. Dalam proses pendampingan ini, tim juga memberikan solusi-solusi atas hambatan yang dihadapi oleh masyarakat melalui komunikasi yang intens. Pendampingan ini dilakukan agar program dapat terlaksana dengan baik atau merupakan penerapan hasil pelatihan yang dilakukan. Peserta pendampingan terdiri dari Kelompok Anggota PKK Dusun Sanggrahan I. 


\section{HASIL DAN PEMBAHASAN}

Hasil dan pembahasan dalam pelaksanaan kegiatan pengabdian masyarakat ini meliputi:

\section{Tahap Persiapan dan Pembekalan}

Tujuan program ini adalah memberdayakan masyarakat Mitra Dusun Sanggarahan I, Desa Muntuk, Dlingo agar menjadi dusun yang dapat secara mandiri melakukan pembuatan kerajinan bambu yang memiliki inovasi dan melakukan pemasaranproduk kerajinan bambu sehingga dapat menghasilkan barang yang memiliki nilai ekonomi. Selain itu, program pengabdian ini juga diharapkan dapat meningkatkan perekonomian masyarakat Dusun Sanggrahan I.

Pemberdayaan masyarakat adalah suatu proses dimana masyarakat mampu meningkatkan pemahamannya secara mandiri. Dalam proses ini, lembaga berperan sebagai fasilitator yang mendampingi proses pemberdayaan masyarakat, yang pada prinsipnya masyarakatlah yang menjalankan program akan tetapi usulan-usulan masyarakat merupakan dasar bagi program. Aspek penting dalam suatu program pemberdayaan masyarakat ialah program dan strategi yang disusun sendiri oleh masyarakat.Pemberdayaan akan berhasil jika dilakukan oleh pengusaha, pemimpin dan kelompok yang dilakukan secara terstruktur dengan membangun budaya kerja yang baik (Santoso, Indarto \& Santoso 2017).

Pelaksanaan pengabdian ini dalam dilaksankan di Dusun Sanggarahan I. Tim Pengabdian pada saat penerjunan sudah dibekali oleh LP3M UMY dan Tim pelaksana pengabdian untuk memperoleh data di lapangan berupa:

a. Observasi. Pada tahap ini, Tim pengabdian sudah melakukan sosialisasi program dan mulai mengajak masyarakat untuk menyampaikan permasalahan dan kendala selama ini;

b. Inventarisasi masalah yang ada di masyarakat Dusun Sanggrahan I yang memerlukan bantuan untuk ditangani oleh tim Pengabdi. Dalam hal ini tim pengabdi memperoleh data bahwa perlu dikembangkannya inovasi pembuatan kerajinan bambu;

c. Meminta anggota kelompok PKK melakukan persiapan bahan kerajinan bambu yang akan dibuat;

d. Melakukan persiapan pemasaran produk kerajinan bambu yang baik.

\section{Tahap Pelaksanaan program}

Program pengabdian masyarakat ini agar berjalan dengan baik dan lancar maka memerlukan tahapan program penyuluhan pembuatan produk kerajinan bambu dan pelatihan pemasaran manual dan online.

a. Penyuluhan dan Praktek Pembuatan inovasi produk kerajinan bambu

Penyuluhan dan praktek pembuatan inovasi produk kerajinan bambu adalah salah satu program pokok yang berkaitan dengan masalah yang sedang dihadapi oleh ibu-ibu Kelompok PKK. Program penyuluhan ini dilaksanakan dengan mengundang narasumber dari salah satu Wirausahawan yang berasal dari daerah Sleman. Program penyuluhan kewirausahaan merupakan program kerjasama Tim Pengabdian UMY, KKN UMY dengan Kelompok PKK. Peserta penyuluhan ini ialah Kelompok PKK Dusun Sanggrahan 1.

Program penyuluhan ini bertujuan untuk memberikan pengetahuan tentang kewirausahaan dan cara pembuatan produk kerajinan bambu seperti tempat pensil, tempat permen, tempat tisu dan vas bunga kepada Kelompok PKK Dusun Sanggrahan 1.Hasil penyuluhan ialah anggota kelompok PKK mendapatkan pengetahuan dan pemahaman mengenai pentingnya berwirausaha dan cara pembuatan kerajinan bambu. Pengetahuan dan kelompok PKK yang semula hanya 50 persen menjadi meningkat sekitar 75 persen.

Setelah dilakukan penyuluhan maka diadakan program praktek pembuatan inovasi produk kerajinan bambu. Program ini bertujuan untuk memberikan pendampingan terhadap pembuatan inovasi produk kerajinan bambu guna meningkatkan ketrampilan, kreatifitas dan inovasi dalam pembuatan kerajinan bambu. 
Pelatih dan Tim Pengabdi mendampingi anggota kelompok PKK untuk membuat produk kerajinan bambu berupa tempat pensil, tempat permen, tempat tisu dan vas bunga berukuran kecil 20-30 cm sesuai permintaan konsumen. Pelatih mendampingi peserta secara satupersatu agar bisa membuat secara mandiri dan memiliki ketrampilan yang berkualitas.

Hasil dari praktek pembuatan inovasi produk kerajinan bambu ialah peserta dapat langsung mempratekkan pembuatan kerajinan bambu dengan berbagai inovasi produk.Setelah adanya pengabdian ini maka yang semula kreatifitasnya masih sangat terbatas dalam membuat kerajinan bambu berupa tampah, tambir, irik, kalo dan ceting menjadi lebih kreatif dan inovatif dalam membuat variasi produk kerajinan bambu berupa tempat pensil, tempat tisu, tempat permen dan tempat boneka.Produk-produk tersebut terbuat dari anyaman bambu yang di bentuk dengan berbagai inovasi dan dihiasi dengan renda atau bunga yang nantinya akan disesuaikan dengan permintaan konsumen. Keterampilan, inovasi dan kreatifitas peserta yang semula 60 persen meningkat menjadi 90 persen.

\section{b. Pelatihan Pemasaran}

Pelatihan ini mengundang salah satu narasumber dari Dosen UMY jurusan ekonomi. Peserta pelatihan ini yaitu Kelompok PKK Dusun Sanggrahan I berusia 25-40 tahun.Program pelatihan pemasaran terdiri dari pemasaran online dan manual. Program pemasaran merupakan program yang dilakukan setelah adanya program pembuatan inovasi produk kerajinan bambu.

Program ini bertujuan agar peserta kelompok PKK memiliki ketrampilan untuk melakukan pemasaran produk kerajinan bambu berupatempat pensil, tempat tisu, tempat permen dan tempat bonekasecara manual maupun online kepada masyarakat luas. Pelatihan ini didampingi oleh Tim Pengabdian dan Pelatih yang berasal dari dosen Fakultas Ekonomi UMY. Peserta kelompok PKK yang diundang ibu kelompok PKK yang berusia 25-40 tahun. Peserta kelompok PKK yang diundang dijadikan tim admin dalam pengelolaan pemasaran. Pemasaran dapat dilakukan secara manual dan online kepada masyarakat baik wilayah D.I Yogyakarta maupun diluar wilayah Yogyakarta.

Pemasaran manual yang dilakukan oleh Ibu Kelompok PKK dengan cara menawarkan produk kerajinan bambu serta membuat form penawaran kepada konsumen yang dituju seperti warga Desa Muntuk, Jogja dan tempat wisata. Beberapa konsumen sangat mengapresiasi hasil kerajinan bambu yang dibuat oleh Kelompok PKK Dusun Sanggrahan 1. Konsumen memberikan saran agar inovasi produk kerajinan bambu lebih dikembangkan dengan berbagai inovasi hiasan di bagian produk kerajinan bambu sehingga minat konsumen akan lebih banyak.

Pemasaran produk kerajinan bambu dapat dilakukan melalui media online yaitu whatsapp, facebook dan media instagram maka kegiatan pelatihan juga membantu memberikan kisi-kisi/trick tentang pemasaran melalui media online(internet).Internet menyediakan platform terknologi universal baru dimana kita dapat membangun semua jenis produk baru, pelayanan, strategis, dan organisasi. Internet juga mengubah cara-cara Sistem Informasi digunakan dalam bisnis dan kehidupan seharihari (Bukit, et,all., 2019).

Pemasaran produk melalui internet berarti memperkenalkan produk kepada konsumen baik dari dalam maupun luarn egeri.Konsumen akan tertarik jika mitra mampu mengolah dan memberikan tampilan web atau fanpage yang menarik sehingga akan meningkatkan jumlah permintaan terhadap produk (Dewi, Aprilia \& Supraptiningsih, 2018).

Hasil pemasaran produk kerajinan bambu yang telah dilakukan oleh anggota PKK Dusun Sanggrahan I secara manual sebelumnya masih sangat tergantung dengan tengkulak. Setelah adanya program pengabdian ini maka Kelompok PKK melakukan pemasaran kerajinan bambu tidak lagi hanya bergantung kepada tengkulak tetapidilakukan dengan menawarkan produk ke toko/swalayan dan secara online melalui akun whatsapp, instagram dan facebook agar lebih mandiri dan meluasnya pemasaran. Ketrampilan anggota Kelompok PKK yang sebelumnya hanya 40 persen menjadi meningkat 70 persen. 
Adapun hambatan yang dihadapi oleh kami adalah kurangnya pendampingan untuk pemasaran dikarenakan waktu pelaksanaan kami yang singkat, dan progress dari masing masing penggerak akun media sosial. Selain itu, jaringan internet yang masih belum maksimal juga menjadi kendala untuk melakukan pemasaran online di Dusun Sanggarahan 1.

Dengan demikian, kegiatan pengabdian ini diperlukan suatu strategi pemasaran yang merupakan rencana menyeluruh, terpadu dan menyatu di bidang pemasaran yang memberikan panduan tentang kegiatan yang akan dijalankan untuk dapat tercapainya tujuan pemasaran suatu perusahaan (Sunarsih \& Umar, 2015). Masing-masing perusahaan tentunya memiliki strategi khusus dan berupaya untuk menjadi paling unggul dibandingkan dengan perusahaan lain.

\section{c. Pendampingan Pemasaran Produk Kerajinan Bambu}

Pendampingan pemasaran produk kerajinan bambu dilakukan oleh Tim Pelaksana Pengabdian setelah berjalannya program pemasaran produk kepada konsumen. Pendampingan ini dilakukan untuk memantau dan mengevaluasi perkembangan pemasaran baik dilakukan secara manual maupun online. Kegiatan ini juga untuk mengukur capaian kegiatan dan mengetahui kendala-kendala yang terjadi pada saat pemasaran dilakukan oleh Kelompok PKK.

Kegiatan ini juga untuk mengajarkan mitra dan masyarakat di sekitar lingkungan usaha mitra agar dapat memperluas daerah pemasaran produk hingga luar kota bahkan sampai tingkat nasional melalui internet (Dewi, Aprilia \& Supraptiningsih, 2018).

Hasil pendampingan pemasaran produk saat tim pengabdi mendampingi anggota kelompok PKK terkait pemasaran produk kerajinan bambu ialah anggota kelompok PKK sudah melaksanakan pemasaran produk baik secara manual dengan menawarkan ke beberapa tetangga sekitar, toko ataupun swalayan di wilayah Yogyakarta. Pemasaran online pun telah dilakukan melaluiakun whatsapp, instagram dan facebook yang telah di miliki oleh admin kelompok PKK sehingga pemasaran produk kerajinan bambu dikenal dan laku terjual di wilayah Yogyakarta dan luar wilayah Yogyakarta

\section{SIMPULAN}

Berdasarkan hasil dan pembahasan diatas maka simpulan dalam pengabdian kepada masyarakat ini ialah anggota kelompok PKK Dusun Sanggrahan 1 yang semula hanya mendapatkan pengetahuan berwirausaha 50 persen meningkat 75 persen dapat mengetahui dan memahami mengenai pentingnya berwirausaha dan cara pembuatan kerajinan bambu.

Ketrampilan kelompok PKK dalam membuat produk semula ketrampilan dan kreatifitasnya masih sangat terbatas dalam membuat kerajinan bambu menjadi lebih trampil, kreatif dan inovatif dalam membuat variasi produk kerajinan bambu berupa tempat pensil, tempat tisu, tempat permen dan tempat boneka.Produk-produk tersebut terbuat dari anyaman bambu yang di bentuk dengan berbagai inovasi dan dihiasi dengan renda atau bunga yang nantinya akan disesuaikan dengan permintaan konsumen. Ketrampilan, inovasi dan kreatifitas peserta yang semula 60 persen meningkat menjadi 90 persen.

Pemasaran produk kerajinan bambu yang telah dilakukan oleh anggota PKK Dusun Sanggrahan I secara manual sebelumnya masih sangat tergantung dengan tengkulak. Setelah adanya program pengabdian ini maka Kelompok PKK melakukan pemasaran kerajinan bambu tidak lagi hanya bergantung kepada tengkulak tetapidilakukan dengan menawarkan produk ke toko/swalayan dan secara online melalui akun whatsapp, instagram dan facebook agar lebih mandiri dan meluasnya pemasaran. Ketrampilan anggota Kelompok PKK dalam pemasaran yang sebelumnya hanya 40 persen menjadi meningkat 70 persen lebih trampil.

\section{UCAPAN TERIMA KASIH}

Saya ucapkan terima kasih kepada Lembaga Penelitian, Publikasi dan Pengabdian Masyarakat Universitas Muhammadiyah Yogyakarta yang telah memberikan hibah program pengabdian masyarakat kepada Tim Pengabdi dan terima kasih kepada Kepala Dukuh serta Kelompok PKK Dusun Sanggrahan I, Desa Muntuk yang telah 
memberikan kesempatan Tim Pengabdi untuk melakukan pengabdian masyarakat sehingga berjalan dengan baik dan lancar.

\section{DAFTAR PUSTAKA}

Anonim. (2018, November).Desa Muntuk, Diunduh dari Desamuntuk.blogspot.com pada tanggal 20 November 2018 pukul 19.00wib.

Anonim. (2018, November). Desa Wisata Muntuk,Di unduh dari dihttps://desawisatamuntuk.wordpress.c om pada tanggal 21 November 2018 pukul 13.00 wib.

Bukit, F.R.A., Gaby, G., Irvan., Fahmi., (2019). Pembuatan Website Katalog Produk UMKM Untuk Pengembangan Pemasaran Dan Promosi Produk Kuliner. Jurnal Pengabdian dan Pemberdayaan Masyarakat, 2 (1), 231.

Dewi, I.N.D.K., Aprilia, I., Supraptiningsih, L.K., (2018). Peningkatan Jumlah Produksi Kerajinan Anyaman Tas Dengan Alat Pemotong Dan Pengukur Tali Pengepak. Jurnal Pengabdian dan Pemberdayaan Masyarakat, 2 (1), 41.

Aini, A.I., Suprapto, R., \& Khaudli, M.I., Izatul, A. (2018). Pemberdayaan Ekonomi Masyarakat Melalui Pemasaran Kuliner Jajanan Tradisional Di Desa Cantuk Kabupaten Banyuwangi. Enggagement : Jurnal Pengabdian Kepada Masyarakat, 2 (2), 168-175
Kotler, P. (2003). Manajemen Pemasaran. Edisi sebelas. Jakarta: PT. Indeks.

Rahmawati, N.L., Zahro, I.F., Asnawi, Mufidah, A.N.E., (2019). Pemanfaatan Pelepah Pisang Menjadi Produk Inovatif Sebagai Upaya Peningkatan Pendapatan Ekonomi Keluarga Di Desa Jamberejo Kecamatan Kedungadem Kabupaten Bojonegoro. Enggagement : Jurnal Pengabdian Kepada Masyarakat. 3 ( 1), 12-31.

Nurdjanah, S., Setyani, S., Satyajaya, W., Hasanudin, U., (2019). Pendampingan Usaha Keripik Tortilla Jagung Pada Kelompok Wanita Tani, Jurnal Pengabdian dan Pemberdayaan Masyarakat, 3 (1), 85-87.

Santoso, D., Indarto, Santoso, A., (2017). Pemberdayaan Usaha Kecil Mikro (UKM) Menuju Kemandirian Melalui Pembinaan Kewirausahaan, Permodalan, dan Pemasaran di Kecamatan Tugu. EDimas : Jurnal Education-Pengabdian Kepada Masyarakat. 8 (2). 166-173

Sunarsih, L., \& Umar, HMS., (2015). Strategi Pemasaran Home Industry Pengrajin Anyaman Bambu Di Desa Gintangan. Jurnal Pendidikan Ekonomi, IX (2),5768

Zamzainudin. (2019). Hasil wawancara dengan Bapak Kepala Dusun Sanggrahan I pada tanggal 9 Januari 2019 pukul 14.00 wib. 